\title{
Peningkatan Pemahaman Konsep Siswa Kelas Vii Smp Lab. Stkip Muhammadiyah Arar pada Mata Pelajaran Ipa Menggunakan Diagram Alir dalam Pembelajaran Inkuiri Terbimbing
}

\author{
Febrian Andi Hidayat \\ Fathurrahman \\ STKIP Muhammadiyah Sorong
}

\begin{abstract}
In general, the level of understanding of concepts in science subjects is achieved by SMP Lab students. Student Learning Outcomes at STKIP Muhammadiyah Arar are in the low category. Many students feel bored and lack enthusiasm in learning. This is due to the lack of varied approaches, models, and methods in learning. The purpose of this study was to improve the understanding of the science concept of seventh grade students of SMP Lab. STKIP Muhammadiyah Arar through Guided Inquiry learning assisted by Flow Charts. This research is a classroom action research, which consists of 2 cycles, where each cycle consists of planning, implementation, observation and reflection. The results showed that the application of Guided Inquiry learning assisted by Flow Charts can improve the understanding of the science concept of Grade VII students in SMP Lab. STKIP Muhammadiyah Arar, which is before the improvement of students who understand the concept only 36\%, after the first cycle reached $64.28 \%$ and after the implementation of the second cycle reached $79.3 \%$.
\end{abstract}

Keywords: Understanding concepts, guided inquiry, flow charts.

Abstrak: Pada umumnya tingkat pemahaman konsep pada mata pelajaran IPA yang dicapai siswa SMP Lab. Hasil Belajar Siswa di STKIP Muhammadiyah Arar termasuk kategori rendah. Banyak siswa yang merasa bosan dan kurang bersemangat dalam belajar. Hal ini disebabkan kerena kurang variatifnya pendekatan, model, maupun metode dalam pembelajarannya. Tujuan penelitian ini adalah untuk meningkatkan pemahaman konsep IPA siswa kelas VII SMP Lab. STKIP Muhammadiyah Arar melalui pembelajaran Inkuiri Terbimbing berbantuan Diagram Alir. Penelitian ini merupakan penelitian tindakan kelas, yang terdiri 2 siklus, dimana masing-masing siklus terdiri dari perencanaan, pelaksanaan, observasi dan refleksi. Hasil penelitian menunjukkan bahwa penerapan pembelajaran Inkuiri Terbimbing berbantuan Diagram Alir dapat meningkatkan pemahaman konsep IPA siswa kelas VII SMP Lab. STKIP Muhammadiyah Arar, yaitu sebelum perbaikan siswa yang paham konsep hanya 36\%, setelah siklus I mencapai 64,28\% dan setelah pelaksanaan siklus II mencapai 79,3\%.

Kata Kunci: Pemahaman konsep, inkuiri terbimbing, diagram alir.

\section{Pendahuluan}

Perkembangan ilmu pengetahuan dan teknologi, pengaruh global, serta seni dan budaya sangat mempengaruhi perkembangan dan perubahan yang terjadi dalam kehidupan bermasyarakat, berbangsa dan bernegara. Perkembangan dan perubahan yang terjadi menuntut adanya peningkatan kualitas pendidikan di Indonesia. Salah satu upaya meningkatkan kualitas pendidikan dapat dilakukan melalui perbaikan dalam proses pembelajaran. Proses pembelajaran mempunyai komponen-komponen yang mempengaruhi hasil belajar di dalamnya yaitu tujuan, bahan atau materi yang dipelajari, strategi, pendekatan, siswa dan guru, media pembelajaran dan penunjang proses pembelajaran lainnya 
(Sugandi, 2008). Pendekatan pembelajaran menjadi salah satu komponen penunjang dalam proses pembelajaran. Pendekatan pembelajaran yang salah akan mengakibatkan kesalahan dalam menentukan strategi, model maupun metode yang digunakan dalam pembelajaran.

Pendekatan yang membudaya dalam proses pembelajaran di Indonesia mengarah pada pendekatan pembelajaran dengan guru sebagai pusatnya (Teacher Centered Approach). Pembelajaran yang pendekatannya terpusat pada guru merupakan proses penanaman pengetahuan pada siswa, dan saat ini dinilai tidak sesuai seiring pesatnya perkembangan teknologi (Hamruni, 2011). Proses penanaman pengetahuan dalam pembelajaran menjadikan siswa sebagai objek belajar dan bukan subjek belajar. Siswa sebagai objek belajar mengarah pada anggapan bahwa siswa merupakan organisme yang pasif, sehingga segala informasi yang diberikan guru harus diterima oleh siswa. Pembelajaran dengan siswa sebagai pusat pembelajaran menyebabkan rendahnya tingkat pemahaman konsep yang akan menyebabkan rendahnya hasil belajar siswa. Tingkat pemahaman konsep dan hasil belajar terlihat secara langsung pada pencapaian siswa, baik dalam pembelajaran sehari-hari maupun selama satu semester. Salah satu mata pelajaran yang dipelajari dan seringkali disalah pahami oleh siswa yaitu mata pelajaran IPA (Hidayat, 2014).

IPA adalah ilmu pengetahuan yang mempelajari mengenai gejala-gejala alam melalui serangkaian proses yang dikenal dengan proses ilmiah. Pembelajaran IPA menjadi salah satu pembelajaran yang kurang diminati oleh sebagian besar siswa di SMP. Kurangnya minat siswa disebabkan karena pelajaran IPA terdiri dari konsep-konsep yang bersifat abstrak. Miskonsepsi pada konsep-konsep IPA seringkali terjadi pada siswa pada proses pembelajarannya. Miskonsepsi siswa pada umumnya disebabkan oleh pemahaman siswa sendiri, serta beberapa faktor lain seperti model, metode, maupun bahan ajar yang digunakan oleh pendidik. Model maupun pendekatan yang digunakan guru dalam mengajar umumnya sama untuk setiap pokok bahasan yang diajarkan, sehingga terkadang tidak sesuai antara pendekatan, model, maupun metode yang dipilih dengan pokok bahasan yang diajarkan. Pemilihan model, pendekatan, maupun metode yang seringkali kurang tepat terjadi pada pembelajaran IPA (Supardi dkk, 2011).

Pembelajaran IPA seharusnya lebih menekankan proses pengaturan lingkungan. Pengaturan lingkungan memungkinkan siswa lebih aktif serta mengalami sendiri konsep yang dipelajari, sehingga siswa tidak sekedar menghafal rumus maupun konsep tetapi dapat memahami konsep dengan lebih baik. Pendekatan inkuiri terbimbing dipadu diagram alir merupakan salah satu pendekatan yang berpusat pada siswa (Student centered approach) yang bersifat mengatur lingkungan. Inkuiri terbimbing merupakan salah satu pendekatan pembelajaran yang memberikan kesempatan pada siswa untuk mengkonstruksi sendiri konsep-konsep yang dipelajari. Siswa dalam pembelajaran inkuiri terbimbing akan mudah memahami konsep yang dipelajari dengan adanya alat bantu yang salah satunya yaitu diagram alir. Diagram alir dalam pembelajaran inkuiri terbimbing bertujuan untuk membantu siswa dalam memahami cara kerja pada percobaan yang dilakukan dalam pembelajaran IPA. Hidayat (2016) dalam penelitiannya memaparkan bahwa pembelajaran menggunakan inkuiri terbimbing yang dipadu dengan diagram alir berpengaruh positif terhadap tingkat pemahaman konsep dan hasil belajar siswa.

Berdasarkan uraian di atas, tingkat pemahaman konsep yang kurang baik dan miskonsepsi dapat dialami oleh siswa yang mempelajari mata pelajaran IPA. Kurangnya pemahaman konsep akan mempengaruhi hasil belajar siswa, sehingga pembelajaran dengan 
pendekatan inkuiri terbimbing dipadu dengan diagram alir mampu meningkatkan pemahaman konsep siswa.

\section{Metode Penelitian}

\subsection{Jenis dan Pendekatan Penelitian}

Jenis penelitian ini adalah Penelitian Tindakan Kelas (PTK) dengan menggunakan pendekatan Inkuiri Terbimbing berbantuan Diagram Alir yang berguna untuk meningkatkan tingkat pemahaman konsep siswa dalam proses pembelajaran IPA. Penelitian ini dilaksanakan dalam 2 siklus, dimana setiap siklus terdiri dari empat tahapan utama sebagai berikut : (1) perencanaan (planning), (2) tindakan (acting), (3) pengamatan (observing), dan refleksi (reflecting), empat tahap kegiatan ini disebut satu siklus pemecahan masalah.

\subsection{Tempat dan Waktu Penelitian}

Penelitian ini dilakukan di SMP Lab. STKIP Muhammadiyah Arar, kampung Arar, Kabupaten Sorong. Penelitian ini dilakukan pada tanggal 1 Agustus s/d 26 September 2018 sebanyak 2 siklus dan setiap siklus terdiri dari 4 pertemuan.

\subsection{Subjek dan Kolaborator Penelitian}

Subjek dalam penelitian ini adalah siswa kelas VII SMP Lab. STKIP Muhammadiyah Arar Kabupaten Sorong Tahun Pembelajaran 2018/2019 yang berjumlah 13 siswa. Objek penelitian ini adalah rendahnya tingkat pemahaman konsep siswa yang lebih tinggi dibanding siswa yang paham konsep pada mata pelajaran IPA melalui penggunaan pendekatan pembelajaran Inkuiri Terbimbing berbantuan Diagram Alir. Sedangkan kolaborator penelitian ini adalah Arif Kukuh Fibrian, S.Pd, guru SMP Lab. STKIP Muhammadiyah Arar.

\subsection{Siklus Penelitian}

Langkah pada siklus berikutnya adalah perencanaan yang sudah direvisi, tindakan, pengamatan, dan refleksi. Sebelum masuk pada siklus 1 dilakukan tindakan pendahuluan yang berupa identifikasi permasalahan. Siklus spiral dari tahap-tahap penelitian tindakan kelas dapat dilihat pada gambar berikut:

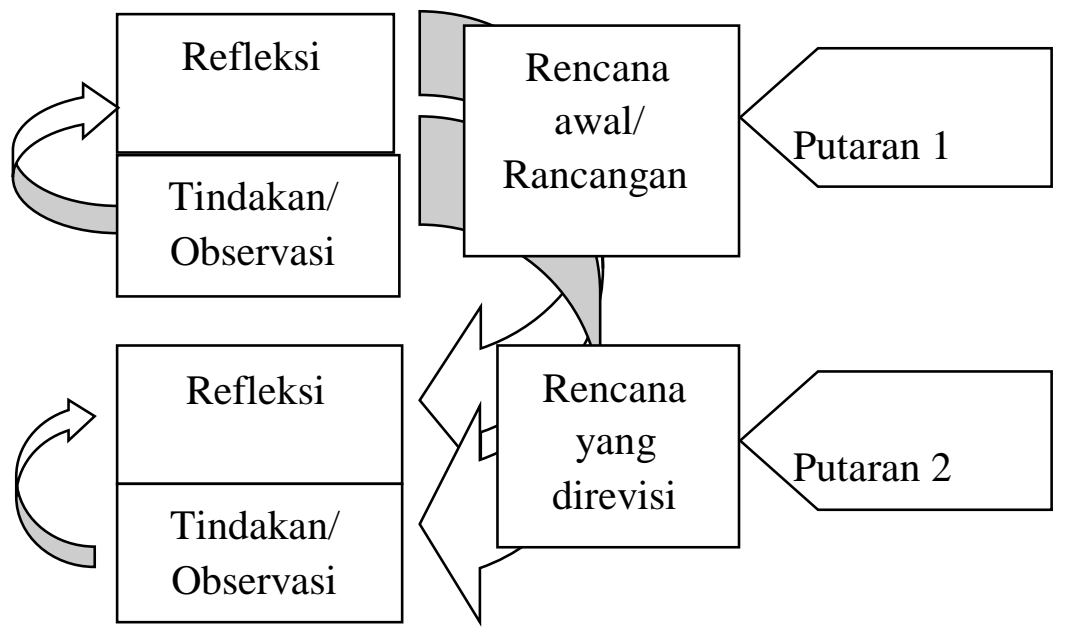

Gambar 1. Alur PTK 
Penjelasan alur di atas adalah:

1. Rancangan/rencana awal, sebelum mengadakan penelitian peneliti menyusun rumusan masalah, tujuan dan membuat rencana tindakan, termasuk di dalamnya instrumen penelitian dan perangkat pembelajaran.

2. Kegiatan dan pengamatan, meliputi tindakan yang dilakukan oleh peneliti sebagai upaya membangun pemahaman konsep siswa serta mengamati hasil atau dampak dari diterapkannya metode pembelajaran pengajaran terarah melalui kegiatan eksperimen.

3. Refleksi, peneliti mengkaji, melihat dan mempertimbangkan hasil atau dampak dari tindakan yang dilakukan berdasarkan lembar pengamatan yang diisi oleh pengamat.

4. Rancangan/rencana yang direvisi, berdasarkan hasil refleksi dari pengamat membuat rancangan yang direvisi untuk dilaksanakan pada siklus berikutnya.

Secara rinci prosedur penelitian tindakan ini dapat dijabarkan dalam uraian, sebagai berikut:

Siklus I

a. Tahap Perencanaan

1). Mengidentifikasi masalah yang timbul selama proses pembelajaran pada pembelajaran IPA.

2). Menganalisis kurikulum untuk mengetahui Kompetensi yang ingin dicapai siswa dalam pembelajaran berdasarkan Kurikulum 2013.

3). Membuat rencana pembelajaranan yang berisikan langkah-langkah penggunaan pendekatan Inkuiri Terbimbing berbantuan Diagram Alir dalam bentuk silabus, RPP, dan LKS.

4). Mempersiapkan sarana pembelajaran yang mendukung terlaksananya tindakan penelitian berupa alat dan bahan untuk eksperimen

5). Mempersiapkan instrument penilaian, yaitu alat evaluasi berupa tes objektif dilengkapi dengan Tinkat Keyakinan Jawaban.

6). Membuat Kriteria Penilaian.

b. Tahap Pelaksanaan (Tindakan)

Saat melaksanakan PTK peneliti harus mengikuti langkah-langkah (prosedur) tertentu agar proses yang ditempuh tepat, sehingga hasilnya dapat dipertanggungjawabkan. Adapun langkah-langkah tindakan yang dilakukan adalah sebagai berikut:

1). RPP sebagai pedoman

2). Membentuk kelompok kerja siswa

3). Membagi lembar kerja siswa

4). Melakukan eksperimen

5). Guru membimbing siswa dalam melakukan ekperimen dan menarik kesimpulan

c. Tahap Pengamatan

Dalam pelaksanaan tindakan dilakukan oleh peneliti sebagai guru di kelas dan di bantu oleh observer sebagai pengamat. Pengamatan yang dilakukan oleh observer adalah untuk mengamati perkembangan proses belajar mengajar yang yang dilakukan oleh guru dan keaktifan siswa dalam proses belajar yang sedang berlangsung, apakah ada kemajuan atau tidak. 


\section{d. Tahap Refleksi}

Pada tahap ini peneliti dan kolaborator sebagai observer merefleksikan kegiatan pembelajaran yang baru berlangsung dan mengkaji berbagai hal yang terjadi dan seharusnya dilakukan dalam pelaksanaan tindakan model PROBEX pada siklus I Siklus II

a. Tahap Perencanaan

1). Mengidentifikasi masalah yang timbul pada proses perbaikan pembelajaran siklus I dan hasilnya ternyata hasil belajar siswa masih rendah.

2). Merancang rencana perbaikan pembelajaran 2

3). Mempersiapkan sarana pembelajaran yang mendukung terlaksananya tindakan penelitian berupa alat dan bahan untuk eksperimen

4). Membuat lembar observasi guru dan siswa serta test evaluasi terhadap materi pembelajaran

b. Tahap Tindakan

Pada penelitian ini dilakukan tindakan yang sama pada siklus I. Setelah melakukan proses pembelajaran, peneliti melakukan tes yang dilakukan bersifat kerja kelompok. Setelah itu diketahui kelemahan yang terdapat pada siswa, peneliti melaksanakan perbaikan terhadap siswa yang memiliki kelemahan dalam mengerjakan soal-soal secara berkelompok.

c. Tahap Observasi (Pengamatan)

Observasi terhadap pelaksanaan tindakan siklus I dan siklus II dengan menggunakan lembar observasi yang telah dibuat. Peneliti mengajar di kelas sedangkan seorang guru yang lain sebagai observer mengisi lembar observasi untuk mengamati kegiatan yang terjadi selama proses belajar mengajar berlangsung melalui pembelajaran Inkuiri Terbimbing berbantuan Diagram Alir dengan tujuan untuk mengobservasi kemajuan dan kelamahan siswa.

d. Analisis dan Refleksi

Pada siklus II peneliti dan pengamat sebagai observan merefleksikan pembelajaran yang baru berlangsung untuk melihat dan mengetahui apakah masih terdapat kesulitan memahami materi ataupun kesulitan dalam menyelesaikan masalah yang berkenaan dengan materi tekanan. Ternyata pada siklus 2 ini hasil belajar sangat meningkat sekali dan sudah mencapai batas ketuntasan belajar siswa. Oleh karena itu penelitian dilakukan hanya sampai siklus II saja.

\subsection{Teknik Pengumpulan Data}

Untuk pengumpulan data dalam penelitian ini dilakukan dengan tes, dan lembar pengamatan atau lembar observasi. Kedua teknik tersebut di uraikan sebagai berikut:

1. Tes dilakukan untuk pengumpulan informasi tentang pemahaman siswa terhadap penggunaan pendekatan Inkuiri Terbimbing berbantuan Diagram Alir pada pembelajaran IPA. Tes dilaksanakan pada awal penelitian, pada akhir setiap tindakan, dan pada akhir setelah diberikan serangkaian tindakan.

2. Wawancara dilakukan guna memperjelas data hasil tes.

\subsection{Teknik Analisis Data}

Teknik analisis data merupakan proses mengatur urutan data, mengorganisasi data ke dalam pola-pola atau kategori uraian dasar. Dalam penelitian ini menggunakan teknik analisis data kualitatif yang dilakukan secara deskriptif interaktif yang dapat digambarkan sebagai berikut: 


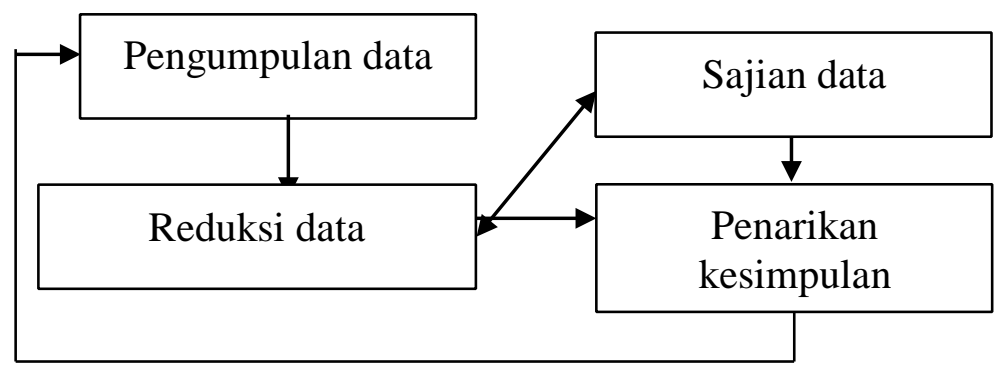

Gambar 2. Teknik analisis data kualitatif

Teknik ini meliputi tiga tahapan utama, yaitu tahap kategori data, tahap interpretasi data, dan tahap penarikan kesimpulan.

1. Tahap kategori data

Pada tahap ini peneliti menyusun data, kemudian mengklasifikasikan menurut uraian permasalahan secara sistematis. Pada tahap ini juga untuk memilih data utama dan data pendukung.

2. Tahap interpretasi data

Data yang telah diperoleh dari hasil penelitian dilakukan penafsiran keadaan data tersebut dengan cermat dan objektif. Dalam tahap ini peneliti juga akan menguji teori-teori yang telah dipaparkan dalam kajian teori, dalam artian data yang diperoleh mendukung atau sebaliknya, yaitu menolak teori-teori tersebut.

3. Tahap penarikan kesimpulan

Tahap ini merupakan jawaban atau simpulan dari masalah yang diteliti dan anggapan dasar yang telah dirumuskan sebelumnya. Dalam tahap ini peneliti juga akan menguji teori-teori yang telah dipaparkan dalam kajian teori, dalam arti kata data yang diperoleh mendukung atau sebaliknya.

\subsection{Indikator Ketercapaian Penelitian}

Indikator Penelitian tercapai didasarkan pada perolehan nilai tes tiap akhir siklus yang mencerminkan pemahaman konsep peserta didik pada materi yang telah diajarkan dengan harapan adanya peningkatan pemahaman konsep sesuai nilai yang diperoleh masing-masing peserta didik yaitu minimal $75 \%$ dari jumlah peserta didik termasuk dalam kategori Paham Konsep dalam tes akhir siklus. Diharapkan minimal $75 \%$ peserta didik telah memahami materi yang disampaikan dengan penerapan pembelajaran Inkuiri Terbimbing berbantuan Diagram Alir.

\section{Hasil dan Pembahasan}

Penelitian ini dilakukan di MTs Sudirman Bantal Kecamatan Bancak Kabupaten Semarang. Alasan peneliti memilih sekolah ini karena peneliti adalah salah satu guru yang mengajar di sekolah ini. Penelitian ini dilakukan pada tanggal 1 Agustus s/d 26 September 2018 sebanyak 2 siklus, tiap siklus terdiri dari 4 pertemuan.

Subjek dalam penelitian ini adalah siswa kelas VII SMP Lab. STKIP Muhammadiyah Arar Kabupaten Sorong Tahun Pembelajaran 2018/2019 yang berjumlah 13 siswa.

\section{Pra Siklus}

Penelitian ini diawali dengan pengamatan yang dilakukan oleh peneliti selama kurang lebih 2 tahun terakhir ini, pembelajaran IPA di VII SMP Lab. STKIP Muhammadiyah Arar masih menggunakan metode yang monoton, seperti metode 
ceramah. Sehingga pemahaman peserta didik kurang optimal akibat dari tingkat keaktifan mereka dalam pembelajaran yang masih sangat rendah. Sebelum dilakukan perlakuan, sebanyak 52\% siswa yang tidak paham konsep sedangkan yang lainnya miskonsepsi dan paham konsep. Sehingga persentase peserta didik yang paham konsep hanya sebesar 35\%. Dari data tersebut terlihat bahwa pembelajaran belum tercapai dikarenakan oleh berbagai hal, salah satunya guru kurang berinovasi memvariasikan pembelajaran dalam kelas.

Kenyataan tersebut mendorong peneliti untuk mengadakan penelitian untuk meningkatkan hasil belajar peserta didik melalui penggunaan pendekatan pembelajaran Inkuiri Terbimbing berbantuan Diagram Alir. Penelitian dilaksanakan dalam 2 siklus.

2. Siklus I

Dalam siklus I pelaksanaan perbaikan pembelajaran yang direncanakan difokuskan pada penerapan pendekatan pembelajaran Inkuiri Terbimbing berbantuan Diagram Alir, sebagai upaya meningkatkan tingkat pemahaman konsep siswa pada mata pelajaran IPA.

a. Tahap Perencanaan

1) Mengidentifikasi masalah yang timbul selama proses pembelajaran pada materi pokok tekanan, yaitu belum meratanya tingkat keaktifan siswa dalam pembelajaran.

2) Membuat rencana pembelajaranan yang berisikan langkah-langkah penggunaan pendekatan pembelajaran Inkuiri Terbimbing berbantuan Diagram Alir. pada materi pokok tekanan. Penyusunan secara mandiri dan setelah itu dikonsultasikan dengan kolaborator sebagai observer.

3) Mempersiapkan sarana pembelajaran yang mendukung terlaksananya tindakan penelitian berupa alat dan bahan untuk eksperimen.

4) Mempersiapkan instrument penilaian, yaitu alat evaluasi berupa tes, tes berjumlah 20 soal berbentuk soal pilihan ganda dilengkapi dengan tingkat keyakinan jawaban untuk mengetahui tingkat pemahaman konsep siswa.

5) Membuat Kriteria Penilaian, yaitu: siswa dikatakan tuntas ketika mencapai persentase siswa yang paham konsep lebih dari $75 \%$.

b. Tahap Pelaksanaan (Tindakan)

Tahap pelaksanaan dalam siklus ini dilakukan dalam satu pertemuan (2X40’) dengan urutan langkah- langkah:

1) Kegiatan pendahuluan

a) Apersepsi

Guru menanyakan kepada siswa : mana jejak kaki diatas tanah yang becek yang lebih dalam ketika ada ayam dan bebek berjalan?

b) Motivasi

- Guru menyampaikan kepada siswa akan pentingnya belajar

- Guru menyampaikan tujuan pembelajaran

2) Kegiatan inti

a) Eksplorasi

Guru membimbing peserta didik dalam pembentukan kelompok, tiap kelompok beranggotakan maksimal 3 siswa

b) Elaborasi

- Guru membagikan lembar kerja siswa 
- Perwakilan tiap kelompok diminta untuk mengambil alat dan bahan eksperimen

- Peserta didik memprediksi jawaban pertanyaan dalam LKS lewat diskusi kelompok

- Guru membimbing peserta didik membuktikan prediksi mereka dengan melakukan eksplorasi lewat eksperimen

- Peserta didik menuliskan hasil eksperimen dan membandingkannya dengan prediksi mereka dilembar kerja

- Peserta didik mempresentasikan hasil diskusi kelompok secara klasikal

- Guru menanggapi hasil diskusi kelompok peserta didik dan memberikan informasi yang sebenarnya

- Peserta didik memperhatikan contoh soal menentukan tekanan dari suatu benda padat yang disampaikan oleh guru

c) Konfirmasi

- Guru bertanya jawab tentang hal-hal yang belum diketahui siswa

- Guru bersama siswa bertanya jawab meluruskan pemahaman, memberikan penguatan dan penyimpulan

3) Kegiatan penutup

a) Guru memberikan penghargaan kepada kelompok yang memiliki kinerja dan kerjasama yang baik

b) Peserta didik (dibimbing guru) berdiskusi untuk membuat rangkuman

c) Guru memberikan soal sebagai evaluasi

c. Tahap Pengamatan

Dalam pelaksanaan tindakan dilakukan oleh peneliti sebagai guru di kelas dan dibantu oleh observer sebagai pengamat. Pengamatan yang dilakukan oleh observer adalah untuk mengamati perkembangan proses belajar mengajar yang yang dilakukan oleh guru dan keaktifan siswa dalam proses belajar yang sedang berlangsung, apakah ada kemajuan atau tidak.

d. Tahap Refleksi

Pada tahap ini peneliti dan kolaborator sebagai observer merefleksikan kegiatan pembelajaran yang baru berlangsung dan mengkaji berbagai hal yang terjadi dan seharusnya dilakukan dalam pelaksanaan tindakan metode eksperimen pada siklus I

Adapun temuan hasil refleksi adalah:

1. Pelaksanaan pembelajaran sudah sesuai RPP

2. Suasana kelas kondusif dan terkendali

3. Pemberian motivasi kepada siswa kurang mengena

4. Pembagian kelompok praktikum dan diskusi kurang homogen (belum merata)

5. Tingkat keaktifan siswa dalam pembelajaran sudah meningkat dari biasanya saat penggunaan metode konvensional walaupun belum merata karena masih didominasi oleh siswa tertentu

6. Pembimbingan dalam eksperimen dan diskusi sudah bagus

7. Pemberian penguatan diakhir pembelajaran sudah bagus

8. Persiapan untuk praktikum (alat dan bahan) kurang matang

Walaupun masih terdapat kekurangan dalam pelaksanaan pembelajaran Inkuiri Terbimbing berbantuan Diagram Alir, ternyata perolehan nilai dan persentase tingkat pemahaman 
konsep siswa meningkat. Pada pembelajaran yang dilaksanakan sebelum perbaikan terlihat bahwa persentase tingkat pemahaman konsep hanya mencapai $35 \%$ pada perbaikan pembelajaran I menjadi $64,28 \%$ sehingga terlihat data peningkatan $28,28 \%$, seperti pada tabel berikut.

Tabel 1. Data hasil tes akhir Siklus I

\begin{tabular}{rlc}
\hline No & \multicolumn{1}{c}{ Kategori } & Persentase \\
\hline 1 & Paham Konsep & 64,28 \\
\hline 2 & Tidak Paham Konsep & 35,72 \\
\hline
\end{tabular}

Meskipun data menunjukkan adanya peningkatan belajar sebesar 28,28\%, yaitu dari sebelum perbaikan sebesar 35\% menjadi 64,28\% namun pembelajaran pada siklus I belum sepenuhnya berhasil. Sebab batas minimal persentase tingkat pemahaman konsep siswa adalah $75 \%$. Oleh karenanya peneliti berupaya memperbaiki pembelajaran.

\section{Siklus II}

Sehubungan masih kurang berhasilnya pembelajaran pada perbaikan pembelajaran siklus I maka peneliti berupaya menemukan faktor penyebab kekurangberhasilan pembelajaran pada siklus I. Dari kegiatan refleksi dan diskusi dengan teman sejawat, serta bantuan dari observer, ditemukan faktor penyebabnya, yaitu penggunaan pendekatan pembelajaran Inkuiri Terbimbing dipadu Diagram Alir yang kurang optimal. Selanjutnya peneliti memfokuskan penelitian perbaikan pembelajaran dengan pendekatan pembelajaran Inkuiri Terbimbing dipadu Diagram Alir yang lebih optimal.

a. Tahap Perencanaan

1). Mengidentifikasi masalah yang timbul pada proses perbaikan pembelajaran siklus I dan hasilnya ternyata hasil belajar siswa masih rendah.

2). Merancang Rencana Perbaikan Pembelajaran 2 yang dibuat secara mandiri dan dikonsultasikan dengan kolaborator.

3). Mempersiapkan sarana pembelajaran yang mendukung terlaksananya tindakan penelitian berupa alat dan bahan untuk eksperimen yaitu botol aqua bekas berukuran $600 \mathrm{ml}$,air , oli bekas dan penggaris

4). Membuat lembar observasi guru dan siswa serta test evaluasi berjumlah 10 soal pilihan ganda terhadap materi pembelajaran

b. Tahap Tindakan

Tahap pelaksanaan dalam siklus ini dilakukan dalam satu pertemuan (2X40') pada hari Sabtu tanggal 14 April 2015 jam ke 3-4 (08.25-09.50 WIB) dengan urutan langkahlangkah:

1. Kegiatan pendahuluan

a. Apersepsi

- Guru memberikan pertanyaan kepada siswa : mengapa pada kaleng yang ringsek yang diisi air dan dilubangi, air akan keluar dari tiap lubang ?

b. Motivasi

- Guru menyampaikan kepada siswa akan pentingnya mempelajari tekanan pada zat cair

- Guru menyampaikan tujuan pembelajaran 
2. Kegiatan inti

a. Eksplorasi

- Guru membimbing peserta didik dalam pembentukan kelompok, tiap kelompok beranggotakan maksimal 3 siswa.

- Guru mengingatkan kepada peserta didik untuk berhati-hati dan cermat dalam melakukan eksperimen

b. Elaborasi

- Guru membagikan lembar kerja siswa

- Perwakilan tiap kelompok diminta untuk mengambil alat dan bahan eksperimen

- Peserta didik memprediksi jawaban dari pertanyaan dalam LKS

- Guru mempresentasikan langkah kerja untuk melakukan eksperimen mengamati tekanan dalam zat cair

- Peserta didik dalam setiap kelompok melakukan eksperimen sesuai dengan langkah kerja yang telah dijelaskan guru

- Guru memperiksa eksperimen yang dilakukan peserta didik, apakah sudah dilakukan dengan benar atau belum. Jika peserta didik atau kelompok ada yang belum melakukannya denga benar, guru dapat langsung memberikan bimbingan

- Peserta didik menuliskan hasil eksperimen dan membandingkannya dengan prediksi mereka dilembar kerja

- Peserta didik mempresentasikan hasil diskusi kelompok secara klasikal

- Guru menanggapi hasil diskusi kelompok peserta didik dan memberikan informasi yang sebenarnya Peserta didik memperhatikan contoh soal menentukan tekanan dalam zat cair yang disampaikan guru

c. Konfirmasi

- Guru bertanya jawab tentang hal-hal yang belum diketahui siswa

- Guru bersama siswa bertanya jawab meluruskan kesalahan pemahaman , memberikan penguatan dan penyimpulan

\section{Kegiatan penutup}

- Guru memberikan penghargaan kepada kelompok yang memiliki kinerja dan kerja sama yang baik

- Peserta didik (dibimbing guru) berdiskusi untuk membuat kesimpulan

- Guru memberikan soal sebagai bahan evaluasi

c. Tahap Observasi (Pengamatan)

Observasi terhadap pelaksanaan tindakan siklus I dan siklus II dengan menggunakan lembar observasi yang telah dibuat. Peneliti mengajar di kelas sedangkan seorang guru yang lain sebagai observer mengisi lembar observasi untuk mengamati kegiatan yang terjadi selama proses belajar mengajar berlangsung melalui penggunaan pendekatan pembelajaran Inkuiri Terbimbing dipadu Diagram Alir dengan tujuan untuk mengobservasi kemajuan dan kelamahan siswa.

d. Analisis dan Refleksi

Pada siklus II peneliti dan pengamat sebagai observer merefleksikan pembelajaran yang baru berlangsung untuk melihat dan mengetahui apakah masih terdapat kesulitan memahami materi ataupun kesulitan dalam menyelesaikan masalah yang berkenaan dengan materi pokok tekanan.

Adapun temuan hasil refleksi pada siklus ini adalah:

1. Perbaikan pelaksanaan sudah sesuai rencana 
2. Persiapan pelaksanaan sudah lebih matamg

3. Pemberian motivasi kepada siswa sudah bagus dan mengena

4. Pembagian kelompok diskusi sudah lebih merata dan homogen

5. Tingkat keaktifan siswa dalam pembelajaran meningkat dengan signifikan

6. Pemberian penguatan diakhir sudah bagus

Ternyata pada siklus 2 ini hasil belajar sangat meningkat sekali dan sudah mencapai batas ketuntasan belajar siswa, seperti ditunjukkan pada tabel 2. Oleh karena itu penelitian dilakukan hanya sampai siklus II saja.

\begin{tabular}{rlc}
\multicolumn{3}{c}{ Tabel 2. Data hasil tes akhir Siklus II } \\
\hline No & \multicolumn{1}{c}{ Kategori } & Persentase \\
\hline 1 & Paham Konsep & 79,3 \\
\hline 2 & Tidak Paham Konsep & 20,7 \\
\hline
\end{tabular}

\subsection{Analisis Akhir}

1. Kognitif

Fokus perbaikan pembelajaran pada siklus I adalah penerapan pembelajaran Inkuiri Terbimbing berbantuan Diagram Alir. Model ini merupakan penerapan metode yang menggambarkan kerjasama dengan siswa aktif dalam kegiatan pembelajaran, yaitu guru memberikan permasalahan, siswa dibimbing guru memprediksi pemecahan permasalahan. Jadi dominasi guru dalam proses pembelajaran menjadi berkurang dan siswa terlibat aktif dalam proses pembelajaran.

Pada kegiatan inti siswa secara berkelompok dengan bimbingan guru memecahkan permasalahan yang berkaitan dengan faktor-faktor yang mempengaruhi tekanan, kemudian dibahas. Guru selalu berusaha mengoptimalkan interaksi antar siswa atau antara siswa dengan guru melalui kegiatan kelompok. Siswa terlibat aktif dalam proses pembelajaran melalui kegiatan diskusi kelompok ataupun diskusi kelas. Pada akhir pembelajaran guru memberikan evaluasi untuk mengetahui tingkat pemahaman siswa terhadap materi yang diajarkan.

Perbaikan pembelajaran pada siklus I menunjukkan adanya peningkatan baik peran guru, persentase pembelajaran maupun persentase ketuntasan belajar. Namun demikian hasil belajar siswa belum maksimal. Dari kegiatan refleksi teridentifikasi bahwa yang menjadi kendalanya adalah kurang optimalnya penerapan pembelajaran Inkuiri Terbimbing berbantuan Diagram Alir dalam pembelajaran, terutama peran serta siswa secara aktif dalam pembelajaran belum maksimal.

Selanjutnya pada siklus II penelitian perbaikan pembelajaran, difokuskan pada penerapan pembelajaran Inkuiri Terbimbing berbantuan Diagram Alir yang lebih optimal. Selama proses pembelajaran, siswa tampak lebih proaktif. Hasilnya ketuntasan belajar siswa mencapai $79,3 \%$ meskipun belum dapat mencapai $100 \%$, namun dapat dikatakan bahwa siswa telah mencapai ketuntasan belajar sebab telah memenuhi standar ketuntasan belajar $75 \%$.

Sampai pada perbaikan pembelajaran siklus II, masih ditemukan beberapa siswa dalam satu kelas yang belum berhasil mencapai nilai tuntas. Hal ini disebabkan karena daya serap siswa terhadap materi sangat rendah, dan motivasi belajarnya kurang.

2. Keaktifan 
Perolehan tingkat keaktifan siswa pada siklus I masih belum optimal yaitu hanya sebesar $62 \%$. Siswa yang aktif dalam pembelajaran belum merata, hanya siswa tertentu saja yang sudah aktif dalam pembelajaran dan siswa yang aktif itu pun sebagian besar merupakan siswa yang sudah aktif sebelum dilakukan tindakan dan juga merupakan siswa dengan tingkat kemampuan akademik tinggi. Siswa yang belum aktif dalam pembelajaran salah satunya disebabkan karena meraka masih merasa takut salah dan malu untuk bertanya, menjawab pertanyaan atau mengemukakan pendapat.

Kurang optimalnya keaktifan siswa pada siklus I juga disebabkan karena siswa belum terbiasa melakukan kegiatan pembelajaran dengan pembelajaran Inkuiri Terbimbing berbantuan Diagram Alir. Kerjasama antar anggota kelompok belum tampak nyata. Kegiatan siswa dalam kelompok masih didominasi oleh siswa yang kemampuan akademiknya tinggi. Siswa yang kurang pandai belum percaya diri untuk mengemukakan pendapatnya dalam kegiatan diskusi. Siswa tampaknya masih perlu berlatih untuk mengemukakan pendapat dan menumbuhkan sikap percaya diri. Hal ini sesuai dengan pendapat Lie yang menyatakan bahwa keterampilan berkomunikasi dalam kelompok, terutama saat memberikan penjelasan (explain) ini juga merupakan proses panjang.

Belum optimalnya peran siswa dalam pembelajaran juga berdampak pada kurangnya tingkat pemahaman siswa terhadap materi yang dipelajari. Pada siklus I ini siswa yang tuntas belajar baru mencapai 64,28\%. Siswa yang turut aktif dalam menemukan konsep tentang materi yang dipelajari akan lebih mudah paham dan mengerti dibandingkan dengan siswa yang hanya sekedar melihat dan mengamati. Hal ini sesuai dengan yang disampaikan Darsono bahwa siswa yang belajar dengan melakukan sendiri akan memberikan hasil belajar yang lebih cepat dan pemahaman yang mendalam.

Keaktifan dan keterlibatan siswa dalam proses pembelajaran merupakan salah satu faktor pendukung keberhasilan belajar siswa. Oleh karena itu sedapat mungkin guru harus mengupayakan agar siswa lebih aktif dan agar mereka berusaha menemukan sendiri suatu konsep yang dipelajari. Guru hanya berperan sebagai fasilitator yang mengarahkan siswa melalui serangkaian kegiatan yang dilakukan siswa seperti melakukan eksplorasi artikel, kegiatan diskusi maupun pengamatan langsung. Hal ini seperti pendapat Mulyasa yang menyatakan bahwa guru sebagai fasilitator merupakan pembimbing proses, orang sumber, orang yang menunjukkan dan mengenalkan kepada peserta didik tentang masalah yang dihadapi.

Berdasarkan hasil analisis data di atas, perlu adanya perbaikan dalam proses pembelajaran selanjutnya. Guru harus lebih banyak memberikan motivasi yang dapat membangkitkan minat belajar siswa sehingga siswa memiliki kepercayaan diri untuk terlibat secara aktif dalam proses pembelajaran. Guru diharapkan dapat memberikan bimbingan dan pemantauan atas jalannya diskusi secara menyeluruh kepada semua kelompok sehingga kegiatan diskusi dapat berkembang dengan baik dan guru dapat mengetahui kesulitan-kesulitan yang dihadapi siswa. Guru harus selalu menciptakan pembelajaran yang menyenangkan bagi siswa, tidak menegangkan, serta memungkinkan siswa untuk terlibat secara langsusng dalam proses pembelajaran. 


\section{Kesimpulan}

Berdasarkan hasil penelitian dan pembahasan dapat ditarik beberapa kesimpulan bahwa "Penerapan pembelajaran Inkuiri Terbimbing berbantuan Diagram Alir dapat meningkatkan Tingkat Pemahaman Konsep Siswa pada Mata Pelajaran IPA siswa kelas VII SMP Lab. STKIP Muhammadiyah Arar Kabupaten Sorong Tahun Pelajaran 2018/2019, yaitu sebelum perbaikan ketuntasan hanya 36\%, setelah siklus I mencapai $64,28 \%$ dan setelah pelaksanaan siklus II mencapai $79.3 \%$.

\section{Daftar Pustaka}

Aqib, Zainal. 2012. Model-model, Media dan Strategi Pembelajaran Kontekstual, Bandung: Yrama Widya

Arikunto, Suharsimi. 2008. Evaluasi Pendidikan, Jakarta: Rineka Cipta

Fatkhurrohman, Pupuh. 2007. Strategi Belajar Mengajar, Bandung, Refika Aditama

Purwanto, M Ngalim. 2006. Ilmu Pendidikan Teoritis, Jakarta: Rineka Cipta

Sardiman AM, 2009. Interaksi dan Motivasi Belajar Mengajar, Jakarta: Rineka Cipta

Sudijono, Anas. 2010. Dasar-dasar Evaluasi Pendidikan, Jakarta: Rajawali Press

Sudjana, Nana. 2008. Pendekatan dalam Pembelajaran, Jakarta: Sinar Baru Algesindo

Supardi. 2006. Penelitian Tindakan Kelas. Jakarta: Rineka Cipta\ Sutanto, Agus. 2008.

Pembelajaran Konstruktivisme. Semarang : Balai Penataran Guru Semarang

Trianto, 2010. Pembelajaran IPA Terpadu, Malang: Pustaka Media

Trianto, 2010. Pembelajaran Konstruktivistik dalam IPA, Malang: Pustaka Media

Wiriatmadja, Rochiati. 2003. Metode Penelitian Tindakan Kelas, Bandung, Remaja

Rosdakarya Yamin, Martinis. 2004. Strategi Pembelajaran Berbasis Kompetensi,

Jakarta: Gaung Persada.

Arikunto, S. (2010). Prosedur Penelitian Suatu Pendekatan Praktik. Jakarta: Rineka Cipta

Depdiknas. (2001). Kamus Besar Bahasa Indonesia Edisi Ketiga. Jakarta: Balai Pustaka.

Iriyanti, N. P. (2012). Identifikasi Miskonsepsi Pada Materi Pokok Wujud Zat Siswa Kelas

VII SMP Negeri 1 Bawang Tahun Ajaran 2009/2010. Jurnal Pendidikan Kimia, 8-13.

Pratomo, Y. N. (2012). Efektivitas Pendekatan Inkuiri Terbimbing terhadap Keterampilan Proses Sains dan Kemampuan Kognitif C1 - C3 Siswa SMP dalam Pembelajaran IPA Materi Pemanasan Global. Tesis S1 pada Fakultas Matematika dan IPA Universitas Negeri Yogyakarta.

Sanjaya, W. (2009). Perencanaan dan Desain Sistem Pembelajaran. Jakarta: Kencana.

Sugiyono. (2006). Statistika untuk Penelitian. Bandung: Alfabeta.

Suparno, P. (2005). Miskonsepsi dan Perubahan Konsep Pendidikan Fisika. Jakarta: Grasindo.

Tayubi, R.T. (2005). Identifikasi Miskonsepsi pada Konsep-konsep Fisika Menggunakan Certainty of Response Index (CRI). Bandung: UPI.

Hidayat, F.A. (2017). Pengaruh Pembelajaran Inkuiri Terbimbing dipadu dengan Diagram Alir terhadap Tingkat Pemahaman Konsep dan Hasil Belajar Siswa Kelas XI IPA SMA Muhammadiyah Jayapura Pada Materi Laju Reaksi. Jurnal Ilmu Pendidikan Indonesia, Vol. 5 (1). 